\title{
The Church Missionary Society and the Rossville Mission Press
}

Joyce M. Banks ${ }^{\dagger}$

There is a wonderful anachronism in the English Bible which provides a most fitting introduction to any consideration of the history of missionary printing, and particularly to the study of the missionary field press in Rupert's Land. It is taken from one of Job's laments:

Oh that my words were now written! oh that they were printed in a book! That they were graven with an iron pen and lead in the rock forever! Job 19:23-24.

An iron pen is a splendid metaphor for the printing press, and graven with an iron pen and lead in the rock forever clearly reflects the aims of the missionary printer, who strove to make an indelible impression. For the Wesleyans and the Anglicans, printing was at work on two levels in Rupert's Land: to achieve the transmission of the scriptures to the aboriginal peoples; and to entrench the syllabic system for a literate society.

In 1853 and 1854 an attempt was made by the Church Missionary Society to gain control of the Rossville Mission in the Hudson's Bay Company territories. Established by the Wesleyan Missionary Society in 1840 , the Rossville Mission was the best situated of any mission in Rupert's Land. At the very hub of the Hudson's Bay Company transportation system, ${ }^{\mathrm{I}}$ it was located at the head of Lake Winnipeg, a few miles from Norway House, which was the marshalling point for the great Rupert's Land fur and freight brigades. The Mission was seven days downstream from York Factory, the

† Joyce M. Banks is Curator of the Rare Book Collection at the National Library of Canada. Her doctoral dissertation, completed at the University of London, is entitled 'Books in Syllabic Characters Printed for the Use of the Church Missionary Society Among the Cree, Saulteaux, Slave and Tukhud Indians and the Eskimos of Little Whale River in the Diocese of Rupert's Land: 1852-1872.' An earlier draft of her paper was read at the Annual Meeting of the Bibliographical Society of Canada in Hamilton, Ontario, on 16 June 1993. 
principal Hudson's Bay Company port. The missionary at Rossville received a stipend of $\mathfrak{2}_{200}$ per annum from the Hudson's Bay Company. ${ }^{2}$ The Rossville Mission also had a printing press.

Three missionary groups served in the Company's territories: the Wesleyan Missionary Society (Methodist), the Church Missionary Society (Anglican), and the Oblats de Marie Immaculée (Roman Catholic). Although policy and practice did not always correspond, the policy of the Hudson's Bay Company was to maintain a balance among the three and to treat all equally. The Wesleyan Missionary Society missions were few in number, but this was offset by Rossville, with its fine location and its press. Despite the differences in their religious philosophies, all three groups recognized the value of books printed in syllabic characters and used them to proselytize, and all three established field presses.

Any discussion of missionary printing in Rupert's Land is indebted to the scholarship of Bruce Peel. His seminal work on James Evans and the Rossville Mission Press as it evolved under the responsibility of the Wesleyan Missionary Society and of the Canada Conference of the Wesleyan Methodist Church has provided a splendid foundation for this paper, which is meant to relate the work of the Church Missionary Society to the Rossville Mission Press. The impact of the Rossville Mission Press on the Oblats de Marie Immaculée has yet to be investigated.

The Rossville Mission Press was the first press in the Hudson's Bay Company territories, and, for twelve years, the only one. It had been established by James Evans of the Wesleyan Missionary Society on his arrival in Rupert's Land in I 840 . Using a makeshift press and home-made types, he printed books for the aboriginal peoples using the syllabic characters, now commonly called 'Cree syllabics.' Within a decade of its introduction, the syllabic system was widespread, and accepted by the aboriginal peoples to the extent that it could then be regarded as the native writing system.

Although James Evans is famous as the printer of Rossville, in fact, he printed only seven books there. He began printing in September I840, and, in I $84 \mathrm{I}$, sent a request to England for a printing press and a fount of syllabic character types, which arrived in 1845 . No printing is recorded between mid-I $84 \mathrm{I}$ and $\mathrm{I} 845,{ }^{3}$ but Peel assumes that some unrecorded items did appear during that period. By the time Evans received his press and types from England, he was unable to use them. He was in ill health, and depressed by his accidental killing of a young convert, Thomas Hassel. Moreover, in I 846, he was being hounded about 'allegations of moral turpitude involving 
Indian women,' a charge of which he was acquitted in a church trial under the Wesleyan discipline which he ordered convened at Rossville. At that time, Sir George Simpson, Governor of the Hudson's Bay Company, wrote to the Wesleyan Missionary Society in London asking that Evans be removed. In I 846 Evans returned to England where he was examined by the Society's secretaries and again found innocent of the charge. He died in the autumn of $1846 .{ }^{4}$ William Mason was the printer at the Rossville Mission Press from I 845 to I854. He carried out an ambitious printing program, and was of key importance to the Church Missionary Society as well as to the Wesleyan Missionary Society.

While the Wesleyan press at Rossville was the first press in Rupert's Land, the Wesleyans were not the first missionaries to serve there. The Church of England, through the Church Missionary Society, had supported missions in the Hudson's Bay Company territories since the early I 820 s, but no book was printed in any aboriginal language for Church Missionary Society use there before the I 850 os. Church Missionary Society missionaries were certainly aware of the Rossville Mission Press. John Smithurst, who served at Indian Settlement, Red River, had two items printed at Rossville in 1848: the National Anthem in English and the English-CreeOjibway Word Book. ${ }^{5}$ Obviously, there was a fount of roman type at Rossville. But it was not until the Anglican missionary Diocese of Rupert's Land was established in I 849, that the attention of the Church Missionary Society was focused on translation and printing of the scriptures and devotional works for use among the aboriginal peoples. The 'primary object' established by the Society for David Anderson, the first Lord Bishop, was 'the translation of the scriptures into Indian language, the printing and dispersing of them. ${ }^{6}$

The success of the 'primary object' depended entirely upon the ability of the peoples to read the books printed for them. For this reason, the Church Missionary Society missionaries chose, or were compelled, to print their books using syllabic characters which were widely used in Rupert's Land by 1849 . For many years there was a conflict between those who favoured the syllabic characters and those who favoured the roman alphabet. When the Diocese of Rupert's Land was established, Anderson's initial response to the syllabic characters was unfavourable. He believed then that the aboriginal people should be taught to read their own languages and dialects using the roman alphabet as a first step towards learning English. ${ }^{7}$ In this he was opposed by Henry Venn, Honorary Secretary 
of the Church Missionary Society, who was not convinced that European civilization was a prerequisite for the establishment and growth of a Christian church. Venn maintained that each society should develop its Christian church within the framework of its own culture. The introduction of books in native languages, he argued, was the first step towards a self-sufficient church. Venn regarded the use of a standard orthography as one of the roots of a sound growth in missions among peoples who did not use the roman alphabet, and he identified the syllabic characters as the orthography to be used in Rupert's Land. This enlightened policy, coupled with Anderson's personal observations of the successful use of the syllabic system among the native peoples of the diocese, persuaded the bishop of its efficacy, and he eventually became a supporter of the syllabic characters. Of major importance in reinforcing Anderson's opinion was the success of the Church Missionary Society field press established at Moose Factory in I 853. Under the direction of John Horden, a capable printer and an excellent translator, the Moose Press issued twenty-three imprints in syllabic characters in some 7,300 copies between 1853 and 1859 for the use of the aboriginal peoples in the James Bay region.

In the 1850 os Rossville Mission Press books in Cree, printed in syllabic characters, were used by the Church Missionary Society, but only two books in syllabic characters were printed at Rossville specifically for Church Missionary Society use. ${ }^{8}$ A prayer book and a hymnal were printed at the request of James Hunter of Cumberland Station on the Saskatchewan River. Although Hunter was an opponent of the syllabic system, he planned to give these little books to the old people in his region who could read and write syllabic characters. ${ }^{9} 500$ copies of the prayer book were printed in the spring of 1853 . The hymnal, translated by Hunter's wife, Jean Ross Hunter, ${ }^{\text {IO }}$ was ordered when Hunter visited Rossville on his way to York Factory in August of that year. 250 copies were waiting for him when he returned the following month. Mason had also prepared 200 copies of the Ten Commandments. At the urging of Anderson, Hunter determined to make use of other Rossville imprints, and, in July I 853 , he ordered a dozen copies of each of Mason's books, except the Conference Rules. ${ }^{\text {II }}$

One other book, the third Rossville edition of the Gospel of St. John, was printed with Church Missionary Society support. In I 852 Mason, the Rossville printer, sent the Secretaries of the Church Missionary Society in London a copy of the first Rossville edition of the Gospel of St. John which had been printed in syllabic charac- 
ters in $185 \mathrm{I} \cdot{ }^{\mathrm{I2}} \mathrm{He}$ also sent a copy to the British and Foreign Bible Society asking for assistance in printing other parts of the scriptures in the same manner. ${ }^{13}$ At that time the British and Foreign Bible Society was engaged in printing James Hunter's translation of the Gospel of St. Matthew in the roman alphabet. The Church Missionary Society advised the British and Foreign Bible Society that both Hunter and the Bishop of Rupert's Land opposed the use of the syllabic system. As a consequence, Mason's request for assistance was refused by the British and Foreign Bible Society. ${ }^{\text {I4 }}$

In I 853 Mason wrote to the British and Foreign Bible Society again, determined to apprise the Editorial Sub-Committee of the true situation in Rupert's Land concerning the use of syllabic characters. He pointed out that the syllabic system had become well established within the past twelve years, and underscored the need for the Gospel of St. John expressed in symbols that the people could read. Several books had been printed at the Rossville Mission Press and circulated throughout the region, and some of them had been used by Church Missionary Society missionaries, but the Rossville Mission Press had never been able to meet the demand for books. Mason also warned of the activities of the Roman Catholic missionaries in Rupert's Land. The Oblats de Marie Immaculée had enjoyed some success among the aboriginal peoples. ${ }^{15}$ At the same time, Mason sent the British and Foreign Bible Society a revised and corrected edition of the Gospel as printed at Rossville, and suggested that 2,000 copies were needed. ${ }^{16}$

Mason had sent Anderson a copy of the British and Foreign Bible Society's 1852 letter of rejection. By I853 Anderson was in favour of the use of syllabic characters in the Diocese of Rupert's Land, and he rallied to Mason's assistance. Anderson approached the British and Foreign Bible Society in support of a third edition of the Gospel of St. John, emphasizing the value of Mason's translation to all living and working in Rupert's Land. He urged the British and Foreign Bible Society to supply at least I,000 copies. ${ }^{17}$ In November I853 the British and Foreign Bible Society Foreign Translation Sub-Committee responded with the recommendation that a grant be made to print $\mathrm{I}, 000$ copies in syllabic characters. ${ }^{18} \mathrm{~A}$ month later Mason wrote to ask the British and Foreign Bible Society to provide a grant of paper to print the books at the Rossville Mission Press rather than undertaking to print the books in London. He thanked the British and Foreign Bible Society for its consideration of the needs of about 5,000 adult aboriginals. He also noted that it was not improbable that the Rossville Mission Press would be transferred to 
the control of the Church Missionary Society. ${ }^{19}$ Mason was voted twenty-five reams of paper at the meeting of the Editorial Sub-Committee on I9 April I854, ${ }^{20}$ to print I,000 copies of the Gospel of St. John in Cree, and for any other portion of the scriptures he might prepare in the same language. No part of the grant was to be used for any other purpose. ${ }^{2 I}$

In 1853 the Council of the Hudson's Bay Company passed a law forbidding the establishment of missions without Company permission. At the same time, the Company raised the price of provisions $^{22}$ to such an extent that the Wesleyan Missionary Society decided that it could no longer afford to support its missions in Rupert's Land. Among its largest expenses was the Rossville Mission Press. Robert Hunt of the Church Missionary Society noted in his journal for 14 November 1853 that he had received sixty copies of the Gospel of St. John for which he had paid I/- each. He reckoned that they had probably cost the Wesleyan Missionary Society $5 /-$ each. ${ }^{23}$

Anderson saw the acquisition of the vacant Wesleyan Missionary Society missions as an opportunity to expand Church Missionary Society influence without the need to petition the Hudson's Bay Company for permission to open new missions, which might have been refused. But, the Wesleyan Missionary Society did not offer the Church Missionary Society its three missions: Rossville, Oxford House, and Lac La Pluie. At the Annual Conference of the Canada Conference of the Wesleyan Methodist Church held in Hamilton, Canada West, 6 June 1853 , the Canada Conference agreed to take responsibility for the Wesleyan Missionary Society missions in Rupert's Land. ${ }^{24}$ They were to be relinquished to John Ryerson, representing the Canadians, in June 1854 . The Canada Conference considered the missions under its control from the time of the Hamilton Conference, ${ }^{25}$ but Anderson believed that he might still acquire the missions before Ryerson's arrival.

In August I 853 Mason wrote to the Wesleyan Missionary Society in London advising the Secretaries of his conviction that the Hudson's Bay Company did not favour the proposed transfer of the missions to the Canada Conference. Mason did not think that the Canadians could superintend the missions as efficiently as the Wesleyan Missionary Society, and he feared that the transfer would result in the loss of a most successful mission. The Wesleyan Missionary Society did not relent, however.

Only in the autumn of that year did Anderson begin his campaign in earnest to acquire the Wesleyan Missionary Society missions, 
especially Rossville. He wrote to Venn of his plans for the Rossville Mission Press. Anderson hoped to expand the printing program to include general books, as well as books in syllabic characters. ${ }^{26} \mathrm{He}$ asked the Wesleyan Missionary Society to reconsider its decision to transfer its missions to the Canada Conference, and offered to indemnify the Wesleyan Missionary Society for the printing equipment at Rossville. He also apprised the Wesleyan Missionary Society of Mason's wish to return to the Church of England, in which he had been baptized, and to enter the service of the Church Missionary Society. ${ }^{27}$

The bishop also wrote to Enoch Wood, Superintendent of the Canada Conference of the Wesleyan Methodist Church, who was responsible for urging the acquisition of the Wesleyan Missionary Society missions in Rupert's Land. Anderson explained the advantages of allowing them to be transferred to the Church Missionary Society in a somewhat untactful letter.

I certainly feel that the Mission work would on the whole proceed better, a large expenditure and outlay would be saved and I think a more favorable impression produced on the Indian mind, if the Wesleyan Society consented to transfer them to the CMS .... I cannot but think that the Canada Conference will find the maintenance of the scattered missions in this land far more expensive than they would imagine. The outlay is, I fancy, larger perhaps than any other mission field, and it is so unavoidably, - but the fewer the missions, the larger comparatively is the outlay. To this I would add that the feelings of all the natives at Rossville are certainly toward myself - in the year 1849 they laid a statement of their case before $\mathrm{me}$, and it was difficult to persuade them that they were not of my immediate charge. I am sure that if they knew there was to be any change, they would at once petition to be placed under my control and be unwilling to be transferred to any other. ${ }^{28}$

The Canada Conference was not moved to reconsider, and Wood wrote a bitter, almost hysterical, letter to the Secretaries of the Wesleyan Missionary Society, condemning both Anderson's efforts and the motives of the Hudson's Bay Company. He described the Company's regime in Rupert's Land as 'absolutism' and the condition of the aboriginal peoples as 'slavery,' with references to 'Sabbath-breaking and a policy to keep the Indian in his wandering habits and dark and untaught mind.' In this, he claimed that the Hudson's Bay Company could manage better with the Roman 
Catholics and the Anglicans than with the Methodist missionaries. ${ }^{29}$

Mason sent his resignation to the Wesleyan Missionary Society in December 1853. In his letter he reviewed the advantages to be gained by allowing the Church Missionary Society control of the Rupert's Land missions. ${ }^{30}$ Both Mason and Anderson remained confident that the Church Missionary Society would prevail. The bishop had the printer, but not the press. He also had the support of the powerful Committee of Correspondence of the Church Missionary Society, whose membership included wealthy and influential Anglican evangelicals. The Committee approached the Wesleyan Missionary Society on his behalf in January I 854 , asking that the mission and press at Rossville be transferred to the Church Missionary Society. ${ }^{3 \mathrm{I}}$ The following month the Wesleyan Missionary Society replied that while there were no objections to Mason's wish to serve the Church Missionary Society, the Wesleyan Missionary Society had transferred all of its property in Rupert's Land to the Canada Conference the previous June. ${ }^{32}$ The Committee of Correspondence instructed Anderson to find out under what terms the Canadians would be willing to relinquish Rossville and its press. ${ }^{33}$ Enoch Wood remained adamant, however, and refused any terms put to him.

Finally, Anderson appealed to the Hudson's Bay Company in London, confident that the Company preferred the Church Missionary Society over the Canadians. He was informed that the Company was powerless to stop the transfer, although the property in question was in the territory under the jurisdiction of the Hudson's Bay Company, and the Company had not been reluctant in the past to interfere in the affairs of both missionary societies and of the Oblats de Marie Immaculée. ${ }^{34}$ When the Wesleyan Missionary Society chose to withdraw from Rupert's Land, the Company decided to forestall the expansionist plans of either the Church Missionary Society or the Oblats de Marie Immaculée. The Company was especially concerned that Anderson should not gain control of all the missions between Red River and York Factory. The law passed by the Hudson's Bay Company Council was meant to limit all missionary groups, but was aimed at Anderson in particular. His willingness to ordain mixed-bloods was disliked by Sir George Simpson. ${ }^{35}$ The bishop caused further offence with his proposal of Robert MacDonald, a mixed-blood, as chaplain to the Hudson's Bay Company at York Factory, which Simpson refused. Anderson had then placed MacDonald at White Dog, later Islington, and was to be 
punished for opening a new mission without Company permission. In the matter of the transfer of the Wesleyan Missionary Society missions, the Company chose not to support Anderson and the Church Missionary Society.

John Ryerson formally took possession of the Wesleyan Missionary Society property in Rupert's Land for the Canada Conference in June I854. Thomas Hurlburt arrived at Rossville in August to replace Mason as missionary and printer, and to supervise the Wesleyan Methodist missions for the Canada Conference. ${ }^{36}$ Anderson made Mason a deacon on 29 June 1854 , and ordained him priest on 25 July. ${ }^{37}$ Mason was appointed chaplain at York Factory. ${ }^{38}$

About the time that Ryerson was taking possession of the Wesleyan Missionary Society missions in June I854, the British and Foreign Bible Society sent Mason an invoice for six bales of paper, shipped aboard the Prince of Wales bound for York Factory. ${ }^{39}$ When the paper arrived, Mason had already transferred to the Church Missionary Society and was installed at York Factory. He wrote to the British and Foreign Bible Society to explain the changes in his circumstances, and to advise the Society that he had given the paper to Ryerson, with a copy of the letter specifying the 'definite and only object for which the paper was granted,' that is, to print I,00o copies of the Gospel of St. John in Cree and other scriptural translations. The Canada Conference planned to send a new press to Rossville, and the paper was to remain at York Factory in storage until it arrived..$^{\circ}$ No press was sent, ${ }^{4 \mathrm{I}}$ but the paper was ultimately forwarded to Hurlburt who used it to print the third Rossville edition of the Gospel of St. John in I 857, the penultimate Rossville Mission Press imprint. ${ }^{42}$

Mason relied upon the Rossville Mission Press during his first years at York Factory because there was no other press to supply his need for books in syllabic characters. He was so remote from the Church Missionary Society press at Moose Factory that it could be of little help to him, although he did receive a few books printed by John Horden in the Moose Cree dialect. ${ }^{43}$ Hurlburt sent Mason books which Mason himself had printed, as well as new Rossville Mission Press imprints.

There was a constant demand for books, and Mason wrote repeatedly of his need for them. But, as Mason and Anderson had foreseen, the Rossville Mission Press did not prosper under the Canada Conference. Hurlburt printed only three books there, 44 of which one was the third edition of the Gospel of St. John, revised and corrected by Mason and his wife, Sophia Thomas Mason, and for 
which Mason had received a grant of paper from the British and Foreign Bible Society, in part through the efforts of Anderson of the Church Missionary Society. Hurlburt returned to Canada in May I 857,45 and no more books were printed at the Rossville Mission Press.

RÉSUMÉ

La presse de la mission de Rossville était créée en I840 par la Wesleyan Missionary Society sur les territoires de la Compagnie de la Baie d'Hudson. Leur but était d'imprimer des livres en caractères syllabiques afin d'évangéliser les autochtones qui utilisaient ces caractères comme leur système d'écriture. Vers I8so la Church Missionary Society adoptait les caractères syllabiques pour leurs traductions de la bible et des ouvrages pieux en langues autochtones et utilisaient les imprimés de la presse de la mission de Rossville. Lorsque la Wesleyan Missionary Society décida de quitter les territoires de la Compagnie de la Baie d'Hudson en I854, la Church Missionary Society essaya en vain de prendre contrôle de la mission de Rossville et de sa presse. 


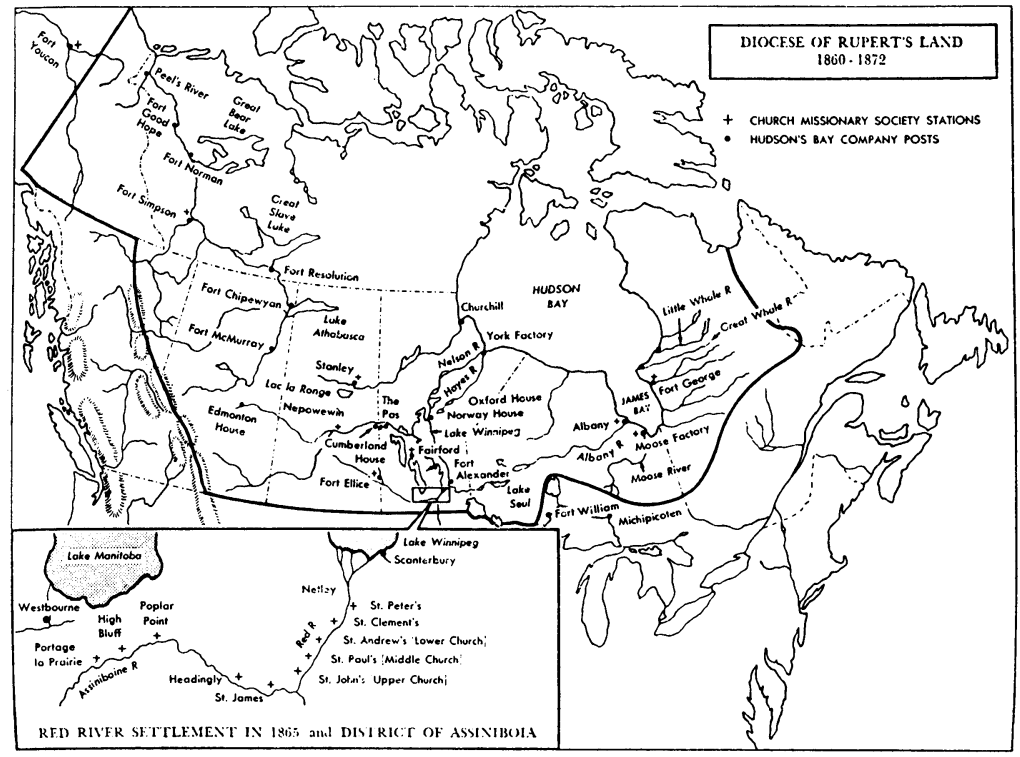

I. The Diocese of Rupert's Land. Rossville was a few miles from Norway House, at the head of Lake Winnipeg. From T.C. Boon's The Anglican Church from the Bay to the Rockies: A History of the Ecclesiastical Province of Rupert's Land and Its Dioceses from I 820 to I950. Toronto: Ryerson Press, I962. 
Q1 $\Delta \cdot 1 i=-\sigma b a b n=$ $\langle\cdot\rangle\langle\psi\rangle \quad b C \nabla \cdot \wedge \sigma$ (.).

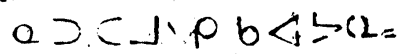

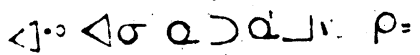
$b \Gamma \cdot 9<2<1.0 \Delta \sigma<11=$ $<\Delta \cdot c$ b" $\Delta q i$ i $\nabla d=$ $N$ irsc<npursut. $\triangle Q$ oNLC.b< $\triangle$ $\triangle V \sigma \cdot C \cdot \rho$ bC $\triangle \dot{L}:$ b. $N_{0}, \nabla t \quad b<<4=$ pNx.

es a l>L -7nbao $c_{-}^{-}$

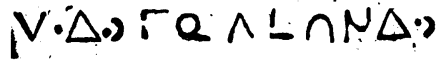

QL $\Delta \cdot a \quad \Delta \Delta \cdot \zeta ?$

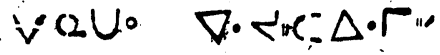
cQ $A d r_{1}>n b \Delta \cdot r_{1}$

QLA.a pbabn= ก d"<U orCL2 0 . bVinกก. b $6 \Omega<\pi^{\circ} \sigma \rho \cap \rho \mu j$.

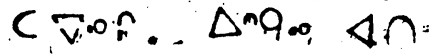
$\wedge Q \bar{v} \cdot\left(s \cdot c \Delta \cdot p_{n}<j b\right)$ Sin $\Delta\left\langle J N_{n} \nabla \nabla\right.$ b.

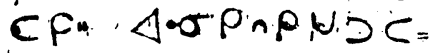
$\nabla \cdot \Delta \because, q \leq A-\cos Q=$

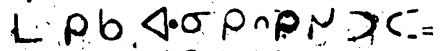
n) in $P \operatorname{LNQDA}$ ocbin rug

No man cometh unto the Father but by Me.

I will not leave Thee, I will come to you in trouble.

Can a woman forget her very own offspring, her suckling child, yes, she may forget, still I will not forget Thee.

See, I have written Thee down on the sole (sic) of my hand.

[p. 15]

2. An example of syllabic characters printed at the Rossville Mission Press, from a book which appeared in $184 \mathrm{I}$. From James Evan's Cree Syballic Hymn Book. Toronto: Bibliographical Society of Canada, I954. (Facsimile Series, no. 4). 
NOTES

I Sir George Simpson to William Mason, 29 June I853. File 273, box 37, reel 25. United Church of Canada Central Archives (hereafter UCA).

2 Dictionary of National Biography. Vol. 7:277; Bruce Peel, The Rossville Mission Press: The Invention of the Cree Syllabic Characters and the First Printing in Rupert's Land (Montreal: Osiris, 1974), 15-16; James Hunter to Henry Venn, 6 January I 854. Microfilm reel A79, Church Missionary Society Archives (hereafter CMSA) C.I/M, National Archives of Canada (hereafter NAC).

3 Peel, The Rossville Mission Press, $\mathrm{I} 6$.

4 Ibid.

5 Ibid., 20-2 I.

6 Venn to David Anderson, 8 March I849. CMSA G/ACI/8 Home Correspondence Book, 1848-73, pp. 97-99. University of Birmingham.

7 Anderson, A Charge Delivered to the Clergy of the Diocese of Rupert's Land at His Primary Visitation (London: Hatchard, $185 \mathrm{I}$ ), 32.

8 Journal of Robert Hunt, October 1852 to June I853, I4 November I852. CMSA C.I/o, NAC-A90; Peel, The Rossville Mission Press, nos. I 8 and 19.

9 Journal of James Hunter, 1852 and I 853,7 January I 853 . CMSA C.I/O, NAC-A9I.

Io Peel, The Rossville Mission Press, no. 18.

I I Ibid., 6 July r 853.

I2 Mason to the Secretaries of the Church Missionary Society, I 3 August 1852. CMSA C.I/O, NAC-A82.

I3 Mason to the British and Foreign Bible Society (hereafter BFBS), I6 August I 852 . BFBS Minutes of the Editorial Sub-Committee, no. 4, p. 90. Cambridge University.

I4 BFBS Minutes of the Editorial Sub-Committee, no. 4, p. 9 I.

I5 Mason to J.W. Meller, 30 August I 853. BFBs Foreign Correspondence. Inward, 1853 .

I6 Peel, The Rossville Mission Press, 27. There is a discrepancy between the imprint date ascribed by Peel for the second Rossville edition of the Gospel of St. John, December 1853 (i.e. Peel no. I6), and the date of Mason's letter to the BFBS, August 1853 . The copy sent to London may have been revised by hand. The book survives, and will be re-examined by this author.

17 Anderson to the Secretary of the BFBS, 3 August I853. BFBS Foreign Correspondence. Inward, 1853 .

I8 BFBs Minutes of the Foreign Translation Sub-Committee, no. 4, p. I I4.

I9 Mason to Meller, 26 December I 853. BFBS Foreign Correspondence. Inward, 1853 .

20 BFBS Minutes of the Editorial Sub-Committee, no. 4, p. 135.

2I Henry Knolleke to Mason, I3 April r854. BFBs Foreign Correspondence. Outwards, 1854 .

22 Mason to the Secretaries of the Wesleyan Missionary Society, I 8 August 1853 . File 273, box 37, reel 25. UCA.

23 Journal of Robert Hunt, October 1852 to June I853. CMSA C.I/O, NAC-A9o.

24 File 273, box 27, reel 25. UCA. 
25 J.H. Riddell, Methodism in the Middle West (Toronto: Ryerson Press, 1946), 40.

26 Anderson to Venn, I I October I853. CMSA C.I/M, NAC-A79.

27 Anderson to the Secretaries of the Wesleyan Missionary Society, I4 October I853. File 273, box 37, reel 25. UCA.

28 Anderson to Enoch Wood, I4 October I853. File 273, box 37, reel 25. UCA.

29 Wood to the Secretaries of the Wesleyan Missionary Society, 23 December 1853. File 273, box 37, reel 25. UCA.

30 Mason to the Secretaries of the Wesleyan Missionary Society, 23 December 1853. File 273, box 37, reel 25. UCA.

3I Minutes of the Committee of Correspondence, I7 January I854. CMSA G/CI Committee Minutes, January 1854 to September 1855 . Vol. 30 , p. 53.

32 Ibid., 98.

33 Ibid.

34 G. Smith (Secretary of the Hudson's Bay Company) to Anderson, 2 I April I854. B/s M/s I 505, Manitoba Provincial Archives.

35 Barbara Benoit, 'Mission at Ile-à-La-Crosse,' The Beaver, Outfit 3 I I, I /Winter I980):40-50.

36 Riddell, Methodism in the Middle West, 43.

37 T.C.B. Boon, The Anglican Church from the Bay to the Rockies: A History of the Ecclesiastical Province of Rupert's Land and Its Diocese from I 820 to I95O (Toronto: Ryerson Press, 1962), 75.

38 Minutes of the Committee of Correspondence, 7 November I854. CMSA G/Cr Committee Minutes, January I 854 to September I855. Vol. 30, pp. 390-9I.

39 Knolleke to Mason, 8 June I 854 . BFBS Foreign Correspondence. Outwards, I 854.

40 Mason to BFBS, I 2 September I 854. BFBS Foreign Correspondence. Inward, I 854 ; Riddell (at p. 43) notes the gift of paper, but makes no mention of the efforts of Anderson and Mason in acquiring the grant from the BFBS.

4I Peel, The Rossville Mission Press, 37.

42 Ibid., no. 2 I.

43 Journal of William Mason, June to December I855. 2 November I855. CMSA C. $\mathrm{I} / \mathrm{O} 44$ (I).

44 Peel, The Rossville Mission Press, nos. 20, 2 I, 22.

45 Peel, The Rossville Mission Press, 37; Riddell, Methodism in the Middle West, 43. 